\title{
礫海岸における摩耗作用を再現する 摩耗促進試験方法の開発
}

\author{
渡辺 国広 1 ・諏訪 義雄 1 -関口 陽高 2 ・野口 賢二 1 . \\ 伊藤 幸義 3 -高田 保彦 4 - 岩佐 隆広 3 -二階堂 竜司5 \\ 1正会員 国土技術政策総合研究所 河川研究部海岸研究室（†305-0804 茨城県つくば市旭一番地） \\ E-mail:watanabe-k92tc@nilim.go.jp, suwa-y22aa@nilim.go.jp, noguchi-k92fu@nilim.go.jp \\ 2正会員 元国土技術政策総合研究所 河川研究部海岸研究室（前田工繊株式会社） \\ （三103-0005 東京都中央区久松町9番9号SCI日本橋ビル5F） \\ E-mail:sekiguchi@mdk.co.jp \\ 3正会員 株式会社建設技術研究所 水理センター（テ300-2651 茨城県つくば市鬼ヶ窪1047-27） \\ E-mail:y-ito@ctie.co.jp,iwasa@ctie.co.jp \\ ${ }^{4}$ 正会員 株式会社新土木開発（テ300-2651 茨城県つくば市鬼ヶ窪1047-27） \\ E-mail:y-takada@ctie.co.jp \\ 5 正会員 株式会社建設技術研究所 河川部海岸海洋室（†330-0071 埼玉県さいたま市浦和区上木崎1-14-6） \\ E-mail:nikaidou@ctie.co.jp
}

\begin{abstract}
静岡県の駿河・富士海岸と富山県の下新川海岸に設置されたコンクリートブロックの摩耗量を調査した 結果, 設置後の経過年数に応じた摩耗量の増加が確認された. 多変量解析によって, 波高, 標高も摩耗速 度に対して有意な影響を及ぼしていることがわかり，現地海岸における摩耗量を推定するモデル式を提示 した。回転ドラム型試験機を用いてコンクリート供試体を摩耗させたところ, 現地海岸と同様の摩耗作用 を再現できることが確認され，現地における摩耗と摩耗促進試験の対応関係を導き出した。この手法を用 いて摩耗させた繊維シートは, 駿河海岸における現地曝露で得られた繊維シートよりも, やや劣化が大き くなる傾向にあったが，本手法によって碩海岸における摩耗耐久性の照査が可能であることが示された.
\end{abstract}

Key Words : geosynthetics, gravel, sand pack, multivariate statistics, test method

\section{1. 研究の背景と目的}

日本の海岸事業では最近，海岸保全事業におけるコス 卜縮减や景観の向上に対する要求から，サンドパックや 袋詰め玉石等のコンクリート以外の素材も利用されるよ うになってきた1)。しかし，海岸における耐久性に対す る不安も根強いため, 短期的な使用や試験施工に留まっ ているのが現状である．より長期間の活用や本施工にま で用途を広げるため，さらには今後の性能向上のために は，現地海岸における耐久性能の評価方法が確立される ことが必要である．特に日本では礫海岸における使用も 想定され，その場合には硯による摩耗劣化への耐久性を 確保することが課題となる．海外では落石による損傷に 耐えるために必要な袋材の単位面積重量や，波浪による 丸石の衝突で損傷しないために必要な袋材の引張強度に ついての知見はあるものの²)，いずれも想定されている のは瞬間的な作用である. 日本の海岸で使用する場合に
は，それらの作用を継続的に受け続けた場合にどれだけ の期間，要求性能を発揮できるかを示すことが求められ るので，これらの照査方法では不十分である。そこで本 研究では，䃯海岸における䃯による摩耗に起因するサン ドパック袋材の経年劣化の照査方法を開発することを目 的とし，現地海岸における摩耗作用の調査およひ現地に おける摩耗作用を再現するための室内実験を実施した.

\section{2. 研究方法}

\section{(1) 研究全体の構成}

現地海岸における摩耗に対するサンドパック袋材の耐 久性を評価するためにはまず，現地海岸における摩耗作 用の強さを把握し，次にその作用を室内実験で再現でき ることが必要となる。しかし，海岸における摩耗作用の 強さの評価方法として確立されたものは存在しないので, 


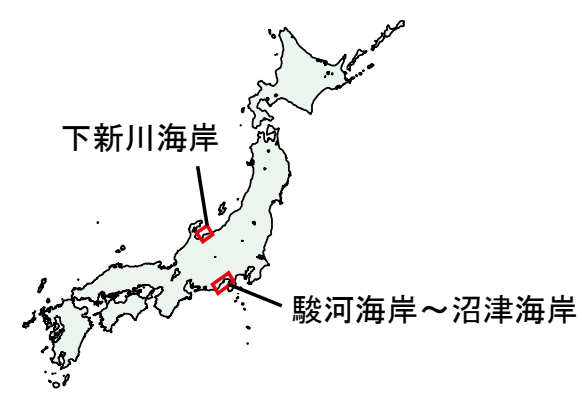

図-1＼cjkstart摩耗量調査を実施した海岸

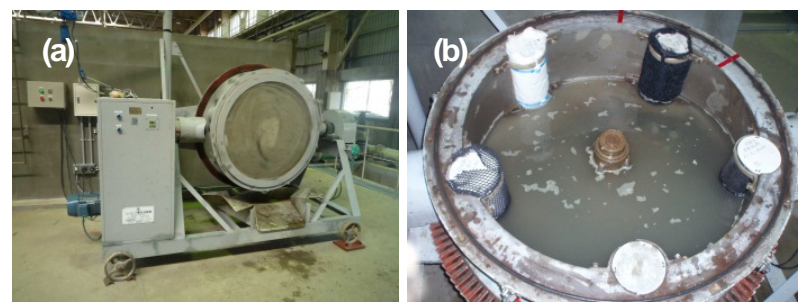

図-2＼cjkstart回転ドラム型試験機(a)および供試体の設置方法(b)

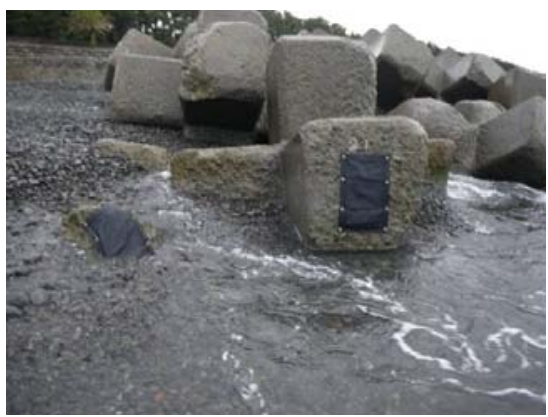

図-3 繊維シートの現地曝露状況

本研究では現地海岸におけるコンクリート構造物の摩耗 量をもつて摩耗作用の大きさを表現することにした。

そのためまず，海岸におけるコンクリートの摩耗量調 査を実施した，続いて同じ摩耗作用を室内で時間を短縮 させて再現できる摩耗促進試験方法を開発し，現地にお けるコンクリートの設置期間と室内試験における試験時 間の対応関係を調べた。こうして作成された試験方法が サンドパック袋材の耐久性評価にも適用できることを確 認するために，繊維シートの現地曝露試験と室内におけ る摩耗促進試験を実施した。

\section{(2) 海岸におけるコンクリート摩耗量調査}

静岡県の駿河海岸焼津地先および富士川周辺の沼津海 岸から蒲原海岸にかけての礫海岸（以降，駿河・富士海 岸）と富山県の下新川海岸において，消波ブロック，緩 傾斜護岸の被覆ブロック等の表面の摩耗量を計測した

（図-1）。計測は摩耗量が小さい箇所については，摩耗 していないブロック面からの摩耗深さを目盛間隔 $1 \mathrm{~mm} の$ 木製直尺によって計測し，摩耗量が大きい箇所について は，原型のブロック形状を推定し，目盛間隔5mmの測量 ロッドで計測した. 海岸の汀線付近における海浜材料の

\begin{tabular}{|c|c|c|}
\hline & $\begin{array}{c}\text { 水セメント比 } \\
(\%)\end{array}$ & $\begin{array}{c}\text { 圧縮強度 } \\
\left(\mathrm{N} / \mathrm{mm}^{3}\right)\end{array}$ \\
\hline 標準配合 & 50 & 27.1 \\
\hline 富配合 & 45 & 29.0 \\
\hline 貧配合 ～～～～～ & 55 & 24.4 \\
\hline 標準配合+シート 1 & - & - \\
\hline 標準配合+シート 2 & - & - \\
\hline
\end{tabular}

粒度分析もあわせて実施し，波浪条件については2001年 から2010年にかけての10年間の有義波高の平均を海象年 表より集計した。駿河・富士海岸については，田子の浦， 久能，駿河海洋の観測所，下新川海岸については田中観 測所における観測結果を使用した。また，設置後の経過 年数については海岸管理者より提供のコンクリートブロ ック等の設置履歴に関する資料をもとに把握した.

\section{（3）コンクリートの摩耗促進試験}

現地におけるコンクリートの摩耗を短時間で再現する 室内試験方法を開発するために，回転ドラム型試験機

（図-2）を用いた摩耗促進試験を試行した。5個のコン クリート供試体を図-2(b)のとおり設置した回転ドラムの 中に, 駿河海岸の汀線付近で採取された中央粒径 $\left(\mathrm{D}_{50}\right) 13 \mathrm{~mm}$ の海浜材料 $10 \mathrm{~kg}$ と水70Lを入れた状態でドラム を図-2(a)のように立てた状態で回転させることで，礫 による摩耗作用を再現した。 この方法では，コンクリー 卜供試体を固定することで形成されるドラム内周の凹凸 によって硯が上方に持ち上げられた後に, 落下すること で下部に位置する供試体への衝突が起きる．また，供試 体による突起が碟を持ち上げる際にこぼれ落ちる礫によ る摩擦も発生する. すなわち2通りのメカニズムによる 摩耗作用が働くものと想定される.

コンクリート供試体は標準的な配合（24-8-40BB）の ものに加えて，富配合，貧配合の計3種類を製作し，供 試体の表面に繊維シートを巻きつけた2検体とあわせて 計5検体を使用した（表-1）。120,000回転させるまでの 間に回転を停止させて，その都度，供試体表面の摩耗量 を計測した。

\section{（4）繊維シートの現地曝露試験}

繊維シートの現地曝露試験は, 駿河海岸の焼津地先で 実施した。繊維シートとして，厚さ0.90mmで紫外線劣 化に対する耐性を高めた黒色ポリエステル製の汎用土木 シートT-500（前田工繊株式会社）を選定して使用した. このシートはあくまでも試験用であり，実際のサンドパ ツク袋材はこれよりはるかに強度が高いものである。こ れを $40 \mathrm{~cm} \times 60 \mathrm{~cm}$ のパネル状に加工し，31枚を汀線付近 の消波ブロックの表面に，ステンレス製のグリップアン 


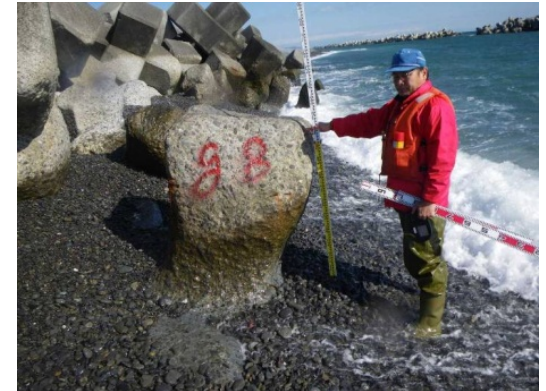

図-4 駿河海岸におけるブロックの摩耗状況

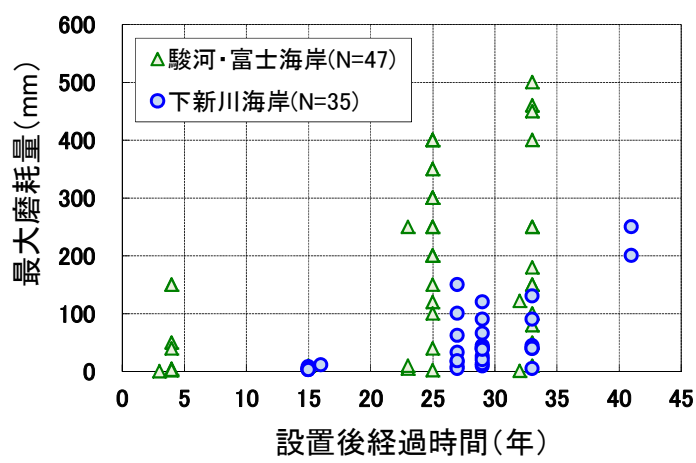

図-5 ブロックの設置後経過年数と摩耗量の関係

カーと全ネジ，ナットで8箇所固定した（図-3）。

曝露試験体は，2010年12月から2011年8月まで設置し， その期間中に5回に分けて回収した. 回収された試験体 から5cm幅に切り出した検体をストリップ法による引張 強度試験（JIS L 1908:2000）に供して, 破断した時点の 荷重を計測することで引張強度を求めた。

\section{(5) 繊維シートの摩耗促進試験}

現地曝露試験で使用したものと同じ規格の繊維シート をコンクリート供試体の表面に巻いた状態で回転ドラム 型試験機に設置し，上述のコンクリートの摩耗促進試験 と同じ海浜材料を使用して, 同じ水と海浜材料の量で摩 耗促進試験をおこなった。回転数は予備実験で繊維シー 卜の破断が確認されている40,000回転を上限とし，回転 数を変えて得た試験体をストリップ法による引張強度試 験に供した。 なお，引張強度試験に必要な検体の長さを 確保できるようにするために，ここで用いるコンクリー 卜供試体は，表面に巻ききれずに余った部分を供試体と ドラム内壁の間に収納できるように円柱の一部を切り欠 いた形状とした.

\section{3. 結果}

\section{(1) 海岸におけるコンクリート摩耗量調査}

現地調查では，ブロックの高い位置にも衝突痕が見ら れた一方で，波浪が直接作用しにくい側面でも明瞭な摩

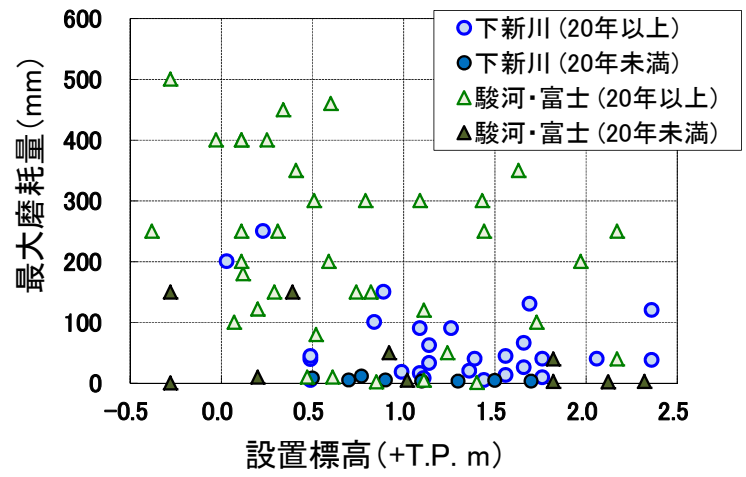

図-6 ブロックの設置標高と摩耗量の関係

表-2 コンクリート摩耗量の計測結果概要

\begin{tabular}{lcc}
\hline & 駿河・富士海岸 & 下新川海岸 \\
\hline 計測地点数 & 7 & 6 \\
中央粒径 $(\mathrm{mm})$ & $6.3 \pm 5.9$ & $31.5 \pm 39.8$ \\
& $(0.35-15)$ & $(0.5-115)$ \\
有義波高 $(\mathrm{m})$ & $0.70 \pm 0.06$ & 0.62 \\
\hline 計測ブロック数 & $(0.65-0.78)$ & 35 \\
経過年数(年) & 47 & $27 \pm 7$ \\
& $(3-33)$ & $(15-41)$ \\
最大摩耗量 $(\mathrm{mm})$ & $180 \pm 148$ & $50 \pm 58$ \\
最大摩耗筒所の & $(0-500)$ & $(3-200)$ \\
標高(T.P.+m) & $0.82 \pm 0.70$ & $1.21 \pm 0.55$ \\
\hline
\end{tabular}

各地点もしくはブロックの平均值士標準偏差, 括弧 内は範囲（最小最大）

耗が見られたことから（図-4），波によって跳ね上げら れた砶の衝突と遡上波の戻り流れによる砶の移動に伴う 摩擦の2通りの摩耗形態があることが推察された.

計測対象としたそれぞれのコンクリートブロックの中 で最も摩耗している箇所における摩耗量を最大摩耗量と 定義し, 設置後の経過年数との関係を示したものが図-5 である．個々のブロック間のばらつきは大きいものの, 最大摩耗量は経過年数に応じて大きくなる傾向にあり, 全体的には駿河・富士海岸のほうが下新川海岸よりも摩 耗量が大きいことが確認された（表-2）．標高と摩耗量 の関係については，駿河・富士海岸も下新川海岸も設置 後20年以上が経過したブロックについては標高が高くな るほど摩耗量が小さくなる傾向がうかがえるえものの, ばらつきが大きいため, 経過年数と摩耗量の関係に比べ れば明膫ではなかった（図-6）。

\section{（2）コンクリートの摩耗促進試験}

回転ドラム型試験機内に固定されたコンクリート供試 体は，ドラムが2,000回転した時点では骨材が露出し始 めただけの状態であったが，120,000回転後の時点では一 部の骨材が剥落するまで摩耗が進行した（図-7）。この ような骨材が露出した摩耗状態は現地海岸のコンクリー トブロックでも多数確認されたものである．120,000回転 

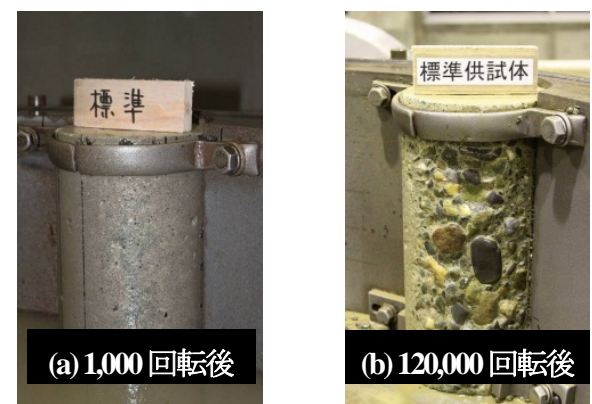

図-7 コンクリート供試体の摩耗状況

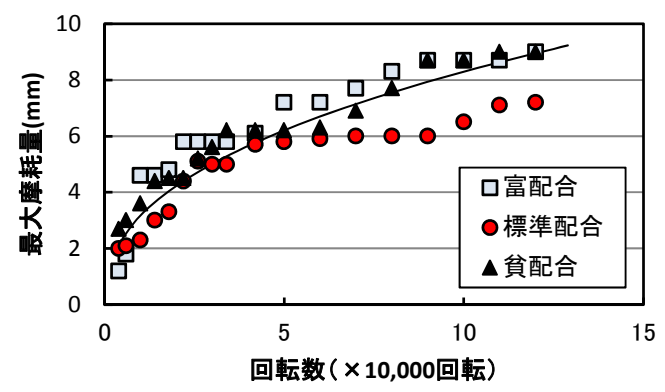

図-8 ドラムの回転数と最大摩耗量の関係

表-3 䋊維シートの曝露日数と引張強度

\begin{tabular}{cccc}
\hline 曝露日数 & 試験体数 & \multicolumn{2}{c}{ 引張強度 $(\mathrm{kN} / 5 \mathrm{~cm})$} \\
\cline { 3 - 4 } 無処理 & 5 & mean \pm s.d. & $\min -\max$ \\
14 & 5 & $5.47 \pm 0.16$ & $8.17-8.63$ \\
58 & 5 & $3.73 \pm 1.24$ & $3.35-7.10$ \\
94 & 5 & $3.75 \pm 1.08$ & $2.20-4.70$ \\
156 & 2 & $2.80 \pm 0.34$ & $2.20-5.57$ \\
275 & $4(3)$ ※ & $2.49 \pm 0.83$ & $2.46-3.14$ \\
埋没 & 3 & - & - \\
不明 & 7 & - & - \\
\hline
\end{tabular}

※4枚のうち1枚は損傷が激しく強度試験できなかった

までの12段階の回転数において計測された各供試体の最 大摩耗量は，40,000回転程度までは回転数にほぼ比例し て急速に大きくなったものの，それ以降は回転数の増加 に比べて摩耗量の増加は針くなっていた（図-8）。全体 を通しての摩耗量は富配合の供試体で最も大きく, 次い で貧配合，標準配合の順となった.

\section{(3) 繊維シ一トの現地曝露試験}

現地に設置した31枚の試験体のうち，埋没・不明とな った10枚を除く21枚を回収することができ，うち20枚を 引張強度試験に供することができた（表-3）。試験体の 引張強度は曝露日数が増えるとともに低下寸る傾向が確 認され，275日後には現地嚗露に供していない無処理の 試験体の29.4\%の強度にまで低下した。

\section{(4) 繊維シ一トの摩耗促進試験}

ドラムの回転数が 8,000 回転以上になった時点で䋊維 シートの表面に毛羽立ち（図-9 (b)）が確認されるよう

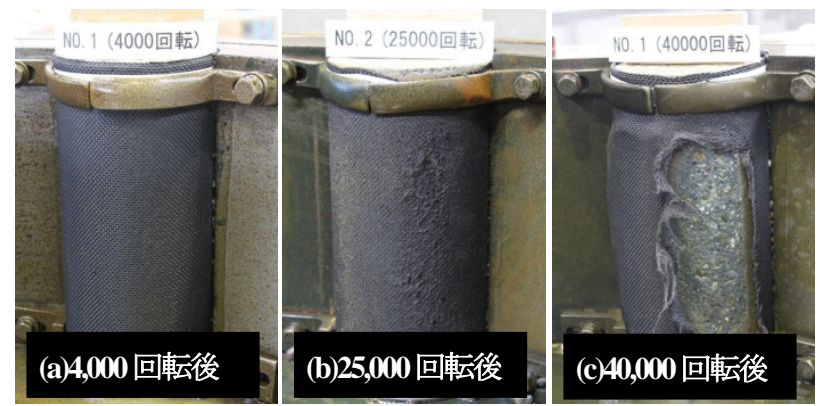

図-9 コンクリート供試体の摩耗状況

表-4 ドラムの回転数と繊維シートの引張強度

\begin{tabular}{cccc}
\hline \multirow{2}{*}{ 回転数 } & \multirow{2}{*}{ 試験体数 } & \multicolumn{2}{c}{ 引張強度 $(\mathrm{kN} / 5 \mathrm{~cm})$} \\
\cline { 3 - 4 } & & mean \pm s.d. & $\min -\max$ \\
\hline 4,000 & 3 & $2.44 \pm 0.13$ & $2.33-2.62$ \\
8,000 & 7 & $0.91 \pm 0.45$ & $0.10-1.66$ \\
9,000 & 1 & 0.70 & - \\
12,000 & 2 & $0.58 \pm 0.11$ & $0.47-0.68$ \\
16,000 & 4 & $0.24 \pm 0.08$ & $0.14-0.37$ \\
17,000 & 2 & $0.15 \pm 0.07$ & $0.08-0.22$ \\
24,000 & 3 & $0.06 \pm 0.02$ & $0.04-0.08$ \\
25,000 & 2 & $0.06 \pm 0.00$ & $0.06-0.07$ \\
32,000 & 2 & $0.04 \pm 0.00$ & $0.04-0.04$ \\
\hline
\end{tabular}

になり，32,000回転では中央部で穴が開き始め，40,000 回転で完全に破損して内部のコンクリート供試体にまで 摩耗作用が及んだ（図-9（c)）。完全な破損に至る手前 の32,000回転までの試験体について引張強度試験を実施 したところ，4,000回転で既に引張強度の平均值は 2.44 $\mathrm{kN} / 5 \mathrm{~cm}$ にまで低下しており（表-4），これは275日間の 現地嚗露を経験した繊維シートの引張強度の平均值 2.49 $\mathrm{kN} / 5 \mathrm{~cm}$ に相当するものであった．その後，24,000回転を 過ぎると引張強度の平均值は $0.1 \mathrm{kN} / 5 \mathrm{~cm}$ 下回り，ほとん ど発揮されなくなった。

\section{4. 考察}

\section{(1) 海岸における摩耗量の決定要素}

現地調査ではコンクリートブロックの摩耗量が経過年 数とともに増大寸る傾向（図-5），標高が高いほど摩耗 量が小さい傾向が確認されたものの（図-6），摩耗量の ばらつきは大きかった。このようなばらつきは，礫によ る摩耗量は経過年数や標高だけでなく, 波浪条件や海浜 材料の粒径，その他の要素にも依存しているために生じ たものと考えられる．そこで，複数の要素を考慮した重 回帰モデルを構筑し，それぞれの要素が摩耗量に及ぼす 影響についての多変量解析を実施した.

まず，海岸における砂による摩耗量を $y(\mathrm{~mm})$, 経過年 数を $x_{1}$ (年)として1年当たりの摩耗量 (摩耗速度) を式(1) のとおり $f\left(x_{2}, x_{3}, x_{4}\right)$ と定義する. 


$$
\mathrm{y}=f\left(x_{2}, x_{3}, x_{4}\right) x_{1}
$$

ここに, $x_{2}$ : 標高 $(\mathrm{m}), x_{3}$ : 波高 $(\mathrm{m}), x_{4}$ : 㗂の粒径 $(\mathrm{mm})$ として, 摩耗速度は磁がブロックに衝突する際のエネル ギー量で決まると仮定すれば, $f\left(x_{2}, x_{3}, x_{4}\right)$ は標高 $\left(x_{2}\right)$ の1乗，波高 $\left(x_{3}\right)$ の2乗，砅の粒径 $\left(x_{4}\right)$ の3乗にそれぞ れ比例すると考えられる. これらによる効果が線形で加 算されると仮定し，摩耗速度を式(2)のとおり表現する.

$$
f\left(x_{2}, x_{3}, x_{4}\right)^{1 / 2}=C_{2} x_{2}^{1 / 2}+C_{3} x_{3}+C_{4} x_{4}^{3 / 2}+\varepsilon
$$

ここに， $C_{2}, C_{3}, C_{4}$ は各要素の影響度を決める係数, $\varepsilon$ はその他の考慮されていない要素による誤差項である 平方根をとったうえで結合しているのは，現地調査で得 られた摩耗速度のデータ数が，小さい值に偏っているこ とによる解析のバイアスを低減させるためである゙

なお，解析にあたっては，駿河・富士海岸と下新川海 岸の双方における調査結果を用い，標高は駿河海岸にお ける朔望平均干潮位（T.P.-1.04m）からの高さとし，波 高は近傍の波浪観測所で得られた有義波高，粒径は汀線 付近の海浜材料の中央粒径とした（表-2）.

多変量解析の結果によれば，波高が有意に影響してお り $(p<0.001)$ ， その次に標高の影響が有意 $(p=0.002)$ である一方で, 粒径の影響は有意でない $(p=0.353)$ と いう結果になった（表-5）。係数を見ると，標高が低く なると摩耗速度が早くなる結果となっており, 図-6で確 認された標高の影響を統計的にも裏付けることができた このことは，摩耗作用が激しい海岸でも，標高の高い場 所に設置するのであれば， サンドパック工の適用が可能 となる場合もあることを意味する。

粒径の違いによる影響については有意性が認められな かったが，粒径が大きくなるとコンクリートに衝突した 時のエネルギーは大きくなる反面，䃇自体が動きにくく なることで衝突の頻度が少なくなるため，今回のモデル で仮定しているような比例関係が成立していないことが 考えられる．また，本研究では磎海岸において現地調査 を実施したものの，表-2で中央粒径の最低值が駿河海岸 で0.35mm，下新川海岸で $0.5 \mathrm{~mm}$ となっいるとおり，地 点によっては前面に砂が堆積していた箇所もあった. こ うした碩海岸における局所的な砂の堆積は一時的なもの

\section{表-5 多変量解析の結果}

\begin{tabular}{lcccl}
\hline & $\mathrm{Cn}$ & $\mathrm{s} . \mathrm{e}$. & $\mathrm{t}$ & \multicolumn{1}{c}{$p$} \\
\hline 標高 $\left(x_{2}^{1 / 2}\right)$ & -1.719 & 0.537 & -3.20 & $0.002^{* *}$ \\
波高 $\left(x_{3}\right)$ & 12.77 & 2.11 & 6.06 & $<0.001^{* * *}$ \\
粒径 $\left(x_{4}^{32}\right)$ & $3.058 \times 10^{-4}$ & $3.276 \times 10^{-4}$ & 0.93 & 0.353 \\
$\varepsilon$ & -4.250 & 1.626 & -2.61 & $0.011^{*}$ \\
\hline
\end{tabular}

$R_{\mathrm{adj}}{ }^{2}=0.389,{ }^{* * *}: p<0.001,{ }^{* *}: p<0.01, *: p<0.05$
であることが多いため，他の大部分の時期においては礫 が主体であった可能性がある.すなわち実際には粒径の 影響を検討できるほどの粒径の違いが無かったことが考 えられる。そのため，本結果のみをもって粒径による 影響が無いと結論付けることは早計である.

\section{（2）摩耗促進試験と現地における摩耗の対応}

本研究では供試体の水セメント比を変えて試験を実施 したが，供試体の圧縮強度と摩耗量の間には関係は見い だせなかった，試験回数が少ないため結論づけるのは早 計であるが，この結果はコンクリートの摩耗耐久性には 他に需要な要素があることを示唆する．以降の検討では 海岸で使用されるコンクリートブロックの強度に地方に よってばらつきがあることも考慮して，配合度の異なる 3種の供試体の結果を分けることなく使用した.

本試験では，コンクリート供試体の摩耗量の増加が回 転数の増加とともに鈍る傾向が確認された（図-8）。こ の原因としてはまず，投入した海浜材料も衝突によって 摩耗もしくは破砕して粒径が小さくなることで衝突の際 のエネルギーが小さくなることが考えられる，実際に試 験後にドラム内の海浜材料を確認したところ，実験開始 時よりも細かくなっていた。 ただし，標準配合の供試体 についての結果によると，5,000回転を過ぎてから摩耗 の進行が停滞したにも関わらず，10,000回転を超えてか ら再び摩耗が進んでおり，海浜材料の粒径低下だけでは この結果を説明できない，そのため，摩耗が進むと図一 7(b) のように骨材が露出することによって摩耗しにく くなったことも摩耗停滞の原因と考えられる.

摩耗量は本来であれば回転数に正比例するはずであ るが，上記のとおり海浜材料の粒径が回転数に応じて減 少寸る効果もあるため, 最大摩耗量 $y_{a b r}$ と回転数 $x_{r o t}$ の 関係は係数 $a, b$ を用いれば次の式(3)に従い， $b$ が1未満 となることが考えられる.

$$
y_{a b r}=a x_{r o t}^{b}
$$

3種類の供試体による実験結果を全て使って式(3)の係 数を求めると, $\mathrm{a}=0.0674, \mathrm{~b}=0.418$ となり, 図-8 中の曲

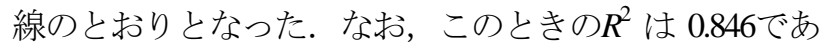
った.この式(3)を式(1)に代入すれば，回転ドラム型試 験機の回転数 $x_{r o t}$ と現地における曝露期間 $x_{1}$ の対応関係 は次の式(4)で表すことができ，現地における摩耗作用 を短時間で再現する摩耗促進試験として利用することが できるようになる.

$$
x_{r o t}=\left(\frac{f\left(x_{2}, x_{3}, x_{4}\right)}{a}\right)^{1 / b} x_{1}^{1 / b}
$$




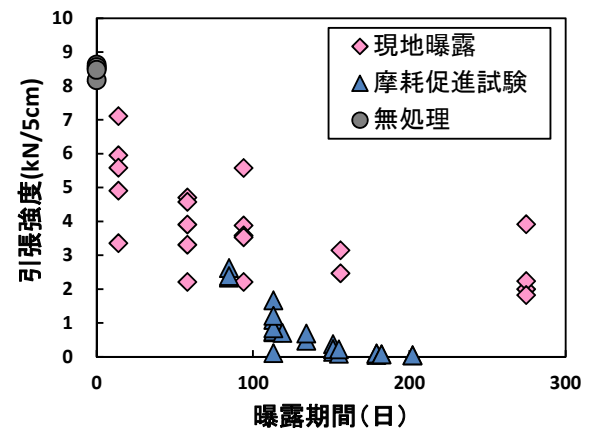

図-10 現地曝露試験と摩耗促進試験の結果の文応関係

\section{（3） サンドパック袋材の摩耗耐久性の照査}

繊維シートについての摩耗促進試験結果を式(4)を用 いて現地における曝露日数に換算し, 現地曝露試験によ って得られた結果と比較した結果を図-10 に示寸。なお 式(2)で摩耗速度を算出するにあたっては，曝露試験を 実施した駿河海岸焼津地先として，標高 0.93+T.P.m，年 平均有義波高 $0.76 \mathrm{~m}$, 海浜材料の中央粒径 $13 \mathrm{~mm}$ とした.

摩耗促進試験の結果は現地における曝露期間100～200 日の間に集中しているが，現地曝露開始から100日目ま での強度低減傾向がそのまま続いたと仮定寸れば，摩耗 促進試験の結果はその延長上にほぼ乗ることが分かる. しかし，実際の曝露試験結果は100日目以降に強度低下 が緩和しており，摩耗促進試験のほうが厳しい評価とな っていた。

この違いの原因としては，摩耗促進試験では䋊維シー トが硬いコンクリート供試体にほぼ隙間無く固定されて いるため，碩の衝突が緩和されることなく袋材に作用す ることが挙げられる．現地曝露した試験体は背面のブロ ックとの間に多少の遊びがあったうえに、表面に藻が生 えた場合もあり，それらが碩の衝突の緩和に寄与したも のと考えられた. サンドパックとして現地に設置する際 には背面が中詰め材となるので，衝撃はさらに緩和され ることになろう。
なお，現地曝露試験の結果は，摩耗のような物理的損 傷だけでなく，紫外線や降雨による化学的劣化も経たう えでの結果であることに留意する必要がある．筆者らが 過去に実施した陸上曝露試験4)で紫外線等による劣化が 100 日間で $1 \mathrm{kN} / 5 \mathrm{~cm}$ 程度であったこと，海水を頻繁にか ぶる場所では紫外線の影響は小さくなることを考えれば 今回の曝露試験結果への影響は大きくないが，設置する 標高や海岸の緯度によっては無視できなくなる.

このような誤差要素はあるものの，摩耗促進試験は現 地よりもやや厳し目の評価となる分には，製品の耐久性 を照査するうえで問題ない，本研究で試行した方法は現 地におけるサンドパック袋材の而摩耗性を短時間で評価 するのに有効と考えられた.

謝辞 : 現地調査を実施するにあたっては，国土交通省北 陸地方整備局黒部河川事務所，同中部地方整備局静岡河 川事務所に，回転ドラム型試験機による試験の立ち上げ にあたっては北陸地方整備局北陸技術事務所，長谷川産 業株式会社，株式会社新土木開発の長谷川昇智朗氏にご 協力を賜った．ここに記して謝意を表する.

\section{参考文献}

1）土橋和敬，弘中淳市，梶原幸治，渡辺国広：西湘海 岸におけるサンドパックの現地試験施工，ジオシン セティック情報誌，2012 年 3 月号，pp.20-30，岩波書 店, 2012 .

2) Pilarczyk, K. W. : Geosynthetics and Geosystems in Hydraulic and Coastal Engineering, Taylor \& Francis, 2000.

3) Grafen, A. and Hails, R. : Modern Statisitcs for the Life Sciences, Oxford University Press, 2002.

4）関口陽高，諏訪義雄，野口賢二，渡辺国広，伊藤幸 義, 岩佐隆広 : サンドパック工法の設計時の耐候性 能決定方法の検討，土木学会論文集 B3（海洋開発）, Vol.68, No.4, pp.I_714-I_719, 2012.

\title{
DEVELOPMENT OF ACCELERATED TEST METHOD FOR EVALUATING THE RESISTANCE TO ABRASION STRESS ON GRAVEL COASTS
}

\author{
Kunihiro WATANABE, Yoshio Suwa, Yoko SEKIGUCHI, Kenji NOGUCHI, \\ Yukiyoshi ITO, Yasuhiko TAKADA, Takahiro IWASA and Ryuji NIKAIDO
}

The degree of abrasion caused by wave-induced gravel attack was measured for concrete blocks settled in Suruga, Fuji, and the Shimoniikawa coast. The depths of erosion were greater on older blocks, and the effects of block elevation and wave height were determined by multivariate statistics. A new accelerated abrasion test was developed to evaluate the resistance to abrasion and puncturing by gravel, and the relationship between the accelerated test results and the degree of abrasion measured on the coasts was investigated. The degree of geosynthetics deterioration was slightly higher for the accelerated test results than for the results of the exposure test carried out on the gravel coast. These results indicate that the newly developed test method is sufficiently reliable for evaluating the endurance of geosynthetics on a gravel coast. 